\title{
Synthesis and cytotoxicity of substituted aromatic curcuminoids against human oral epidermal carcinoma-KB cell line
}

\author{
Vo Thi Nga ${ }^{1}$, Phan Phuoc Hoai Nhan ${ }^{2}$, Pham Nguyen Kim Tuyen ${ }^{3}$, Hoang Minh Hao ${ }^{1}{ }^{*}$
}

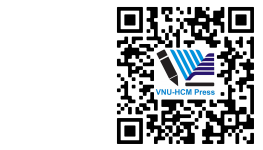

Use your smartphone to scan this QR code and download this article

${ }^{1}$ Faculty of Chemical and Food Technology, Ho Chi Minh City University of Technology and Education

${ }^{2}$ Faculty of Natural Sciences Pedagogy, Sai Gon University

${ }^{3}$ Faculty of Environmental Science, Sai Gon University

\section{Correspondence}

Hoang Minh Hao, Faculty of Chemical and Food Technology, Ho Chi Minh City University of Technology and Education

Email: haohm@hcmute.edu.vn

History

- Received: 2021-02-17

- Accepted: 2021-04-07

- Published: 2021-5-12

DOI : 10.32508/stdj.v24i2.2517

\section{Check for updates}

\section{Copyright}

(c) VNU-HCM Press. This is an openaccess article distributed under the terms of the Creative Commons Attribution 4.0 International license.

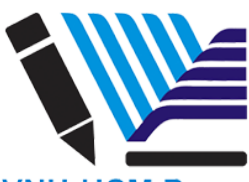

VNU-HCM Press

\begin{abstract}
Introduction: The survival rate of oral cancer, like other types of cancers, has not been improved regardless of the early diagnosis and the introduction of advanced therapies. Treatment for oral cancer includes surgery, radiation therapy, and chemotherapy. However, the effectiveness has been limited due to recurrence and undesirable side effects. Metabolites from plant sources have been shown to be relatively less toxic and thus are considered as potential anti-cancer agents. Interestingly, curcumin isolated from the rhizome of Curcuma longa L. possesses broad-spectrum bioactivities. We focused on the synthesis of curcumin-based analogs bearing $-\mathrm{OH} /-\mathrm{OCH}_{3} /-\mathrm{F}$ groups on the phenyl rings in our continuous efforts to search for curcumin-based anti-cancer agents. The synthesized compounds were subsequently evaluated for the cytotoxic activities against KB cancer cell line (an epidermal carcinoma of the mouth)

Methods: The desired curcuminoids were synthesized via aldol reactions between benzaldehyde derivatives and pentane-2,4-dione using $n$-butylamine as a catalyst. Structures were distinguished by NMR and MS spectra. The cytotoxic activity against KB was determined through the half-maximal inhibitory concentration $\left(\mathrm{IC}_{50}, \mu \mathrm{M}\right)$.

Results: Six curcumin analogs (1-6) were successfully synthesized in a yield of $48-76 \%$. The 3hydroxy/fluoro curcumin analogs $\left(\mathbf{3}, I C_{50}=15.61 \pm 0.13 \mu \mathrm{M} ; \mathbf{6}, I C_{50}=22.65 \pm 1.76 \mu \mathrm{M}\right)$ exhibited better anti-cancer activities when compared to curcumin $\left(\mathbf{1}, I C_{50}=33.35 \pm 2.66 \mu \mathrm{M}\right)$, whereas the para-fluoro substitution patterns displayed lower inhibitory activities $(\mathbf{4}, \mathbf{5})$ against KB cancer cell line.

Conclusions: The synthetic yields are dependent on the position and nature of substituents in aromatic rings. The presence of electron-donating groups gives products (1-3) in lower yields when compared to those (4-6) prepared from fluorinated benzaldehydes as starting materials. The curcuminoids bearing - $\mathrm{OH}$ groups at para-positions in aromatic rings $(\mathbf{1}, \mathbf{2})$ can be responsible for better inhibition of cell growth, whereas the fluoro-substituted compounds $(\mathbf{4}, \mathbf{5})$ make a negative contribution to inhibitory activity. Furthermore, the contributions -OH/-F groups at meta-position in aromatic rings of $(\mathbf{3}, \mathbf{6})$ on the cytotoxicity against $\mathrm{KB}$ are remarkable and firstly reported in our findings.

Key words: Curcumin analogs, anti-cancer activity, aldol condensation, KB cancer cell line
\end{abstract}

\section{INTRODUCTION}

$\mathrm{KB}$ cell line has been known to be a subline of the KERATIN-forming tumor cell line HeLa and was originally derived from an epidermal carcinoma of the mouth ${ }^{1}$. Oral cancer, known as lip, tongue and mouth cancers, is a serious and growing problem with more than 350,000 cases worldwide and about half of the patients died from it ${ }^{2}$. Despite the early diagnosis and the introduction of advanced therapies, the survival rate of oral cancer patients has not been improved $^{3}$. The conventional treatments for oral cancer involving primary surgery followed by radiotherapy and/or chemotherapy are limited in effectiveness, recurrence, and undesirable side effects. In recent years, there has been a global trend toward natural products extracted from plant sources. Several phytochemicals have been selective, potent, and relatively less toxic and thus are considered potential anti-cancer agents in clinical cancer chemotherapy ${ }^{4}$.

Curcumin (1), a constituent of turmeric powder derived from the rhizome of C. longa, is an attractive compound with broad-spectrum capacities including anti-oxidant ${ }^{5}$, anti-inflammatory ${ }^{6}$, and antitumour ${ }^{7}$ activities. In particular, many studies reported that curcumin exhibited anti-cancer activity in a wide range of human cancers ${ }^{8-15}$. In addition, curcumin is pharmacologically safe as large quantities of curcumin, up to $10 \mathrm{~g}$ per day, can be consumed without inflicting toxicity ${ }^{16}$. However, despite the multiple potentials of curcumin, its clinical applications until now are limited due to its poor solubility in water, low chemical stability, and poor oral bioavail- 
ability $^{17}$. To overcome these limitations, chemical modification of the curcumin structure is one of the promising approaches to explore curcumin-based analogs, which improve the therapeutic profile of the mother compound ${ }^{8-12}$. Structure-activity relationship (SAR) analysis on curcumin analogs revealed that the aromatic ring and its substituents are necessary for biological activities ${ }^{10-13}$. In view of this, benzaldehyde analogs bearing various functional groups in the phenyl ring were selected as starting materials to condense with pentane-2,4-dione under basic conditions to afford analogs of curcumin ${ }^{10-13,18,19}$. Within this framework, curcumin analogs containing hydroxy/methoxy/fluorine groups on phenyl rings were synthesized in our work, and their in vitro anticancer activities against oral cancer cells (KB) were assessed.

\section{METHODS}

\section{Synthetic procedure for curcuminoids (1-6)}

The published procedurewas used to carry out the synthetic procedure of curcuminoids (1-6) bearing various substituents on aromatic rings ${ }^{12,13,18,19}$ (Figure 1). A mixture of boron oxide $(10.0 \mathrm{mmol})$ and pentane-2,4-dione $(10.0 \mathrm{mmol})$ in ethyl acetate $(20.0 \mathrm{~mL})$ was stirred at $70{ }^{\circ} \mathrm{C}$ for $1 \mathrm{~h}$ in a $100-\mathrm{mL}$ two-neck round-bottom flask to yield the solution of acetylacetone-borate complex. Benzaldehyde (20.0 mmol) and tri- $n$-butyl borate $(40.0 \mathrm{mmol})$ was next added, and the resulting mixture was stirred for 30 min. While stirring, $n$-butylamine $(4.0 \mathrm{mmol})$ was added dropwise over $30 \mathrm{~min}$. The resulting mixture was stirred and heated at $70{ }^{\circ} \mathrm{C}$ for $4-4.5 \mathrm{~h}$ (monitored by TLC using HEX/EA = 3/2 for 1-3; 95/5 for 4, 6; $9 / 1$ for 5 as eluent). The reaction mixture was treated with an aqueous $\mathrm{HCl}$ solution $(0.1 \mathrm{~N}, 20 \mathrm{~mL})$ with stirring for $1 \mathrm{~h}$, then extracted with DCM (40 $\mathrm{mL} \times 3$ ). The combined organic layers were dried over $\mathrm{Na}_{2} \mathrm{SO}_{4}$ concentrated in vacuo. The residue was purified by flash column chromatography $\left(\mathrm{SiO}_{2}\right.$, eluent: $\mathrm{HEX} / \mathrm{EA}=20 / 1$ to $7 / 3$ ) to afford the pure products. The eluates from flask CC were fractionated by TLC using a mixture of HEX/EA as eluent.

\section{Analytical methods}

Nuclear magnetic resonance (NMR) spectra of curcuminoids (1-6) were recorded on a Bruker Avance $\left(500 \mathrm{MHz}\left({ }^{1} \mathrm{H}\right), 125 \mathrm{MHz}\left({ }^{13} \mathrm{C}\right)\right)$. Mass spectrometry (MS) measurements were performed on an AGILENT 1200 series LC-MSD. Sample spots on TLC were detected by UV light at $\lambda=254$ and $365 \mathrm{~nm}$. Melting points (m.p) of pure products were determined by M5000 apparatus with a heating rate of $2.0^{\circ} \mathrm{C} / \mathrm{min}$.

\section{Cytotoxicity assay against KB cancer cell} line

Curcuminoids (1-6) were tested in vitro for their cytotoxic activities against the $\mathrm{KB}$ cancer cell line. The assay was carried out at the Laboratory of Applied Biochemistry, Institute of Chemistry, Vietnam Academy of Science and Technology using a MTT method (the assay procedure can be found in the Supporting Information).

\section{RESULTS}

Target curcuminoids (1-6) were synthesized following the published procedure from literature in 48$76 \%$ yields $^{12,13,18,19}$ (Table 1). Chemical structures were elucidated by NMR and MS spectra (see the Supporting Information for ${ }^{1} \mathrm{H},{ }^{13} \mathrm{C}-\mathrm{NMR}, \mathrm{HSQC}$, and MS spectra). All synthesized compounds were evaluated for cytotoxicity against human oral epidermal carcinoma-KB cell line using MTT method. The inhibitory activities were determined through their half-maximal inhibitory concentration $\left(\mathrm{IC}_{50}, \mu \mathrm{M}\right)$ (Table 1).

$(1 E, 4 Z, 6 E)$ - 5-hydroxy-1,7 - bis(4-hydroxy-3methoxyphenyl)hepta - 1,4,6-trien-3-one (1): Yield 53\% (1.95 g), red-orange solid, $\mathrm{C}_{21} \mathrm{H}_{20} \mathrm{O}_{6}$ [368.13 g/mol]; $R_{f}=0.31$ (HEX/EA = 3/2); m.p. 182.3 ${ }^{\circ} \mathrm{C}{ }^{1} \mathrm{H}-\mathrm{NMR}\left(500 \mathrm{MHz}, \mathrm{CDCl}_{3}\right): \delta(\mathrm{ppm})=3.96(s$, $\left.\mathrm{OCH}_{3}, 3 \mathrm{H}\right), 3.95\left(s, \mathrm{OCH}_{3}, 3 \mathrm{H}\right), 6.42\left(s, \mathrm{H}_{4}, 1 \mathrm{H}\right)$, $6.83\left(d, \mathrm{H}_{1},{ }^{3} J(\mathrm{H}, \mathrm{H})=16.0 \mathrm{~Hz}, 1 \mathrm{H}\right) ; 6.93\left(d, \mathrm{H}_{5^{\prime}}\right.$, $\left.{ }^{3} J(\mathrm{H}, \mathrm{H})=8.0 \mathrm{~Hz}, 1 \mathrm{H}\right), 6.94\left(d, \mathrm{H}_{5^{\prime \prime}},{ }^{3} J(\mathrm{H}, \mathrm{H})=8.0\right.$ $\mathrm{Hz}, 1 \mathrm{H}), 6.99\left(d, \mathrm{H}_{7},{ }^{3} J(\mathrm{H}, \mathrm{H})=16.5 \mathrm{~Hz}, 1 \mathrm{H}\right), 7.02-$ $7.08\left(\mathrm{H}_{2^{\prime}, 2^{\prime \prime}, 6^{\prime}, 6^{\prime \prime}}, 4 \mathrm{H}\right), 7.11\left(d, \mathrm{H}_{2},{ }^{3} J(\mathrm{H}, \mathrm{H})=16.5 \mathrm{~Hz}\right.$, $1 \mathrm{H}), 7.29\left(d, \mathrm{H}_{6},{ }^{3} J(\mathrm{H}, \mathrm{H})=16.5 \mathrm{~Hz}, 1 \mathrm{H}\right) .{ }^{13} \mathrm{C}-\mathrm{NMR}$ $\left(125 \mathrm{MHz}, \mathrm{CDCl}_{3}\right): \delta(\mathrm{ppm})=55.9\left(\mathrm{OCH}_{3}\right), 55.9$ $\left(\mathrm{OCH}_{3}\right), 97.6\left(\mathrm{C}_{4}\right), 108.2\left(\mathrm{C}_{2^{\prime}}\right), 108.8\left(\mathrm{C}_{2^{\prime \prime}}\right), 110.9$ $\left(\mathrm{C}_{5^{\prime}}\right), 113.8\left(\mathrm{C}_{5^{\prime \prime}}\right), 114.6\left(\mathrm{C}_{6^{\prime}}\right), 114.8\left(\mathrm{C}_{6^{\prime \prime}}\right), 121.5\left(\mathrm{C}_{2}\right)$, $121.6\left(\mathrm{C}_{6}\right), 128.2\left(\mathrm{C}_{1^{\prime}}\right), 128.5\left(\mathrm{C}_{1^{\prime \prime}}\right), 134.8\left(\mathrm{C}_{1}\right), 135.6$ $\left(\mathrm{C}_{7}\right), 146.7-146.9\left(\mathrm{C}_{4^{\prime}, 4^{\prime \prime}, 3^{\prime}, 3^{\prime \prime}}, 4 \mathrm{C}\right), 162.1\left(\mathrm{C}_{5}\right), 168.5$ $\left(\mathrm{C}_{4}\right)$. ESI-MS $m / z$ calc for $[\mathrm{M}+\mathrm{H}]^{+}:$369.14; found: 368.90 .

(1 $E, 4 Z, 6 E$ )-5-hydroxy-1,7-bis(4-hydroxyphenyl) hepta- 1,4,6 -trien-3-one (2):

Yield 48\% (1.48 g), orange solid, $\mathrm{C}_{19} \mathrm{H}_{16} \mathrm{O}_{4}[308.10$ $\mathrm{g} / \mathrm{mol}] ; R_{f}=0.45(\mathrm{HEX} / \mathrm{EA}=3 / 2) ;$ m.p. $213.5^{\circ} \mathrm{C}$; ${ }^{1} \mathrm{H}-\mathrm{NMR}\left(500 \mathrm{MHz}, \mathrm{DMSO}-d_{6}\right): \delta(\mathrm{ppm})=6.04$ $\left(s, \mathrm{H}_{4}, 1 \mathrm{H}\right), 6.68\left(d, \mathrm{H}_{2,6},{ }^{3} J(\mathrm{H}, \mathrm{H})=16.0 \mathrm{~Hz}, 2 \mathrm{H}\right)$, $6.82\left(d, \mathrm{H}_{3^{\prime}, 3^{\prime \prime}, 5^{\prime}, 5^{\prime \prime}},{ }^{3} J(\mathrm{H}, \mathrm{H})=8.5 \mathrm{~Hz}, 4 \mathrm{H}\right), 7.52-$

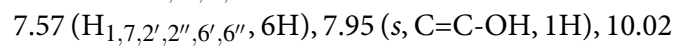
$\left(s, \mathrm{C}_{6} \mathrm{H}_{4}-\mathrm{OH}, 2 \mathrm{H}\right) .{ }^{13} \mathrm{C}-\mathrm{NMR}(125 \mathrm{MHz}, \mathrm{DMSO}-$ $\left.d_{6}\right): \delta(\mathrm{ppm})=100.8\left(\mathrm{C}_{4}\right), 115.8\left(\mathrm{C}_{3^{\prime}, 3^{\prime \prime}, 5^{\prime}, 5^{\prime \prime}}\right), 120.7$ $\left(\mathrm{C}_{2,6}\right), 125.8\left(\mathrm{C}_{1^{\prime}, 1^{\prime \prime}}\right), 130.2\left(\mathrm{C}_{2^{\prime}, 2^{\prime \prime}, 6^{\prime}, 6^{\prime \prime}}\right), 140.3\left(\mathrm{C}_{1,7}\right)$, 159.7-162.3 $\left(\mathrm{C}_{4^{\prime}, 4^{\prime \prime}}\right), 183.1\left(\mathrm{C}_{3,5}\right)$. ESI-MS $m / z$ calc for $[\mathrm{M}+\mathrm{H}]^{+}$: 309.11 ; found: 308.90 . 


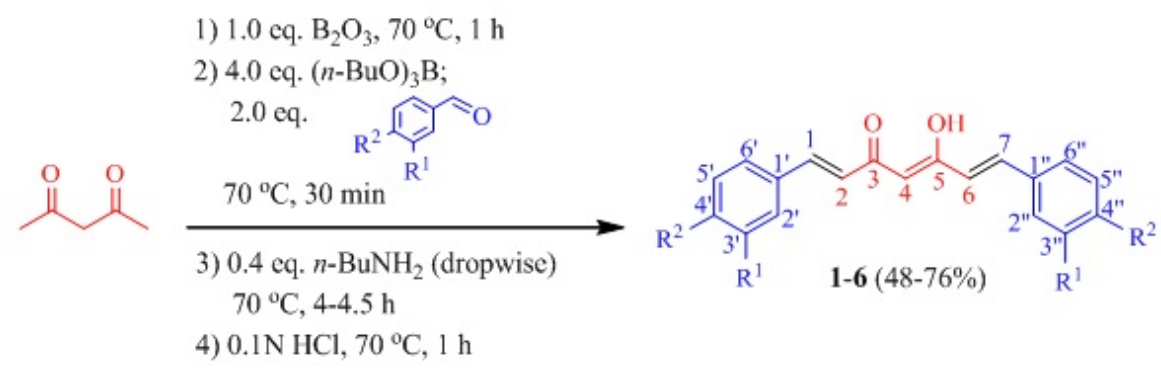<smiles>COc1cc(/C=C/C(=O)/C=C(O)/C=C/c2ccc(O)c(OC)c2)ccc1O</smiles><smiles>O=C(/C=C/c1ccc(F)c(F)c1)/C=C/c1ccc(F)c(F)c1</smiles><smiles>O=C(/C=C/c1ccc(F)cc1)/C=C/c1ccc(F)cc1</smiles><smiles>O=C(/C=C/c1cccc(O)c1)/C=C/c1cccc(O)c1</smiles><smiles>O=C(/C=C/c1cccc(F)c1)/C=C/c1cccc(F)c1</smiles>

Figure 1: The synthetic procedure and structures of curcuminoids (1-6).

Table 1: Reaction time, isolated yields, and IC $50(\mu \mathrm{M})$ values against KB cancer cell line of curcuminoids (1-6).

\begin{tabular}{llll}
\hline Compound & Time (h) & Yield (\%) & $\mathrm{IC}_{50} \pm \mathrm{SD}^{[a]}(\mu \mathrm{M})$ \\
1 & 4.5 & 53 & $33.35 \pm 2.66$ \\
2 & 4 & 48 & $43.94 \pm 3.18$ \\
3 & 4 & 55 & $15.61 \pm 0.13$ \\
4 & 4 & 72 & $66.36 \pm 5.80$ \\
5 & 4 & 66 & $366.19 \pm 28.48$ \\
6 & 4 & 76 & $22.65 \pm 1.76$ \\
\hline
\end{tabular}

${ }^{[a]}$ MTT viability assay after $72 \mathrm{~h}, \mathrm{n}=3$, mean $\pm \mathrm{SD}$.

(1 E,4 Z ,6 E )-5-hydroxy-1,7-bis(3-hydroxyphenyl) hepta- 1,4,6 -trien-3-one (3):

Yield 55\% (1.69 g), yellow solid, $\mathrm{C}_{19} \mathrm{H}_{16} \mathrm{O}_{4}[308.10$ $\mathrm{g} / \mathrm{mol}] ; R_{f}=0.43(\mathrm{HEX} / \mathrm{EA}=3 / 2) ;$ m.p. $185.5{ }^{\circ} \mathrm{C}$; ${ }^{1} \mathrm{H}-\mathrm{NMR}\left(500 \mathrm{MHz}, \mathrm{DMSO}-d_{6}\right): \delta(\mathrm{ppm})=6.22$ $\left(s, \mathrm{H}_{4}, 1 \mathrm{H}\right), 6.81\left(s, \mathrm{H}_{2,6}, 2 \mathrm{H}\right), 6.84\left(m, \mathrm{H}_{4^{\prime}, 4^{\prime \prime}}, 2 \mathrm{H}\right)$, $7.07\left(d, \mathrm{H}_{2^{\prime}, 2^{\prime \prime}},{ }^{3} J(\mathrm{H}, \mathrm{H})=1.5 \mathrm{~Hz}, 2 \mathrm{H}\right), 7.15\left(d, \mathrm{H}_{6^{\prime}}, 6^{\prime \prime}\right.$, $\left.{ }^{3} J(\mathrm{H}, \mathrm{H})=7.5 \mathrm{~Hz}, 2 \mathrm{H}\right), 7.24\left(d d, \mathrm{H}_{5^{\prime}}, 5^{\prime \prime},{ }^{3} J(\mathrm{H}, \mathrm{H})\right.$ $\left.=7.5 \mathrm{~Hz},{ }^{3} J(\mathrm{H}, \mathrm{H})=7.5 \mathrm{~Hz}, 2 \mathrm{H}\right), 7.56\left(d, \mathrm{H}_{1,7},{ }^{3}\right.$ $J(\mathrm{H}, \mathrm{H})=16.0 \mathrm{~Hz}, 2 \mathrm{H}), 9.63\left(s, \mathrm{C}_{6} \mathrm{H}_{4}-\mathrm{OH}, 2 \mathrm{H}\right) .{ }^{13} \mathrm{C}-$ NMR (125 MHz, DMSO- $\left.d_{6}\right): \delta(\mathrm{ppm})=100.6\left(\mathrm{C}_{4}\right)$,
$114.5\left(\mathrm{C}_{2^{\prime}, 2^{\prime \prime}}\right), 117.5\left(\mathrm{C}_{4^{\prime}, 4^{\prime \prime}}\right), 119.3\left(\mathrm{C}_{6^{\prime}, 6^{\prime \prime}}\right), 124.1$ $\left(\mathrm{C}_{2,6}\right), 129.9\left(\mathrm{C}_{5^{\prime}, 5^{\prime \prime}}\right), 135.9\left(\mathrm{C}_{1^{\prime}, 1^{\prime \prime}}\right), 140.5\left(\mathrm{C}_{1,7}\right)$, $157.7\left(\mathrm{C}_{3^{\prime}, 3^{\prime \prime}}\right), 183.1\left(\mathrm{C}_{3,5}\right)$. ESI-MS $m / z$ calc for $[\mathrm{M}+\mathrm{H}]^{+}:$309.11; found: 308.80 .

$(1 E, 4 Z, 6 E)-\quad 1,7 \quad$-bis(3,4-difluorophenyl)- 5 -hydroxyhepta- 1,4,6 -trien-3-one (4):

Yield 72\% (2.50 g), yellow solid, $\mathrm{C}_{19} \mathrm{H}_{12} \mathrm{~F}_{4} \mathrm{O}_{2}$ [348.08 $\mathrm{g} / \mathrm{mol}] ; R_{f}=0.48(\mathrm{HEX} / \mathrm{EA}=95 / 5) ;$ m.p. $212.3^{\circ} \mathrm{C}$; ${ }^{1} \mathrm{H}-\mathrm{NMR}\left(500 \mathrm{MHz}, \mathrm{CDCl}_{3}\right): \delta(\mathrm{ppm})=5.81\left(, \mathrm{H}_{4}\right.$, $1 \mathrm{H}), 6.52\left(d, \mathrm{H}_{2,6},{ }^{3} \mathrm{~J}(\mathrm{H}, \mathrm{H})=16.0 \mathrm{~Hz}, 2 \mathrm{H}\right) ; 7.19(m$, $\left.\mathrm{H}_{5^{\prime}, 5^{\prime \prime}}, 2 \mathrm{H}\right), 7.27\left(m, \mathrm{H}_{2^{\prime}, 2^{\prime \prime}}, 2 \mathrm{H}\right), 7.37\left(m, \mathrm{H}_{6^{\prime}, 6^{\prime \prime}}, 2 \mathrm{H}\right)$, 
$7.57\left(d, \mathrm{H}_{1,7},{ }^{3} J(\mathrm{H}, \mathrm{H})=16.0 \mathrm{~Hz}, 2 \mathrm{H}\right) ;{ }^{13} \mathrm{C}-\mathrm{NMR}$ $\left(125 \mathrm{MHz}, \mathrm{CDCl}_{3}\right): \delta(\mathrm{ppm})=102.1\left(\mathrm{C}_{4}\right), 116.1-$ $117.9\left(\mathrm{C}_{5^{\prime}, 5^{\prime \prime}, 6^{\prime}, 6^{\prime \prime}}\right), 124.9\left(\mathrm{C}_{2,6}\right), 124.9\left(\mathrm{C}_{2^{\prime}, 2^{\prime \prime}}\right), 132.2$ $\left(\mathrm{C}_{1^{\prime}, 1^{\prime \prime}}\right), 138.5\left(\mathrm{C}_{1,7}\right), 150.6\left(d, \mathrm{C}_{4^{\prime}},{ }^{1} J(\mathrm{C}, \mathrm{F})=247.5\right.$ $\mathrm{Hz}), 150.7\left(d, \mathrm{C}_{4^{\prime \prime}},{ }^{1} J(\mathrm{C}, \mathrm{F})=248.7 \mathrm{~Hz}\right), 151.3(d$, $\left.\mathrm{C}_{3^{\prime}},{ }^{1} J(\mathrm{C}, \mathrm{F})=251.2 \mathrm{~Hz}\right), 151.4\left(d, \mathrm{C}_{3^{\prime \prime}},{ }^{1} J(\mathrm{C}, \mathrm{F})=\right.$ $251.2 \mathrm{~Hz}), 182.8\left(\mathrm{C}_{3,5}\right)$; ESI-MS $m / z$ calc for $[\mathrm{M}+\mathrm{H}]^{+}$: 349.09; found: 348.80 .

$(1 E, 4 Z, 6 E)-\quad 1,7 \quad$-bis(4-fluorophenyl)- 5 hydroxyhepta- 1,4,6 -trien-3-one (5):

Yield 66\% (2.06 g), yellow solid, $\mathrm{C}_{19} \mathrm{H}_{14} \mathrm{~F}_{2} \mathrm{O}_{2}[312.10$ $\mathrm{g} / \mathrm{mol}] ; R_{f}=0.34(\mathrm{HEX} / \mathrm{EA}=9 / 1) ;$ m.p. $185.7{ }^{\circ} \mathrm{C}$; ${ }^{1} \mathrm{H}-\mathrm{NMR}\left(500 \mathrm{MHz}, \mathrm{CDCl}_{3}\right): \delta(\mathrm{ppm})=5.81(s$, $\left.\mathrm{H}_{4}, 1 \mathrm{H}\right), 6.54\left(d, \mathrm{H}_{2,6},{ }^{3} J(\mathrm{H}, \mathrm{H})=16.0 \mathrm{~Hz}, 2 \mathrm{H}\right)$, $7.08\left(d d, \mathrm{H}_{3^{\prime}, 3^{\prime \prime}, 5^{\prime} .5^{\prime \prime}},{ }^{3} J(\mathrm{H}, \mathrm{H})=8.5 \mathrm{~Hz},{ }^{3} J(\mathrm{H}, \mathrm{H})=2.0\right.$

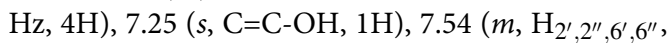
$4 \mathrm{H}), 7.62\left(d, \mathrm{H}_{1,7},{ }^{3} J(\mathrm{H}, \mathrm{H})=16.0 \mathrm{~Hz}, 2 \mathrm{H}\right) .{ }^{13} \mathrm{C}-$ NMR $\left(125 \mathrm{MHz}, \mathrm{CDCl}_{3}\right): \delta(\mathrm{ppm})=101.7\left(\mathrm{C}_{4}\right)$, 116.0-116.2 $\left(\mathrm{C}_{3^{\prime}, 3^{\prime \prime}, 5^{\prime} .5^{\prime \prime}}\right), 123.7-123.8\left(\mathrm{C}_{2,6}\right), 129.9$ $129.9\left(\mathrm{C}_{2^{\prime}, 2^{\prime \prime}, 6^{\prime}, 6^{\prime \prime}}\right), 131.2-131.3\left(\mathrm{C}_{1^{\prime}, 1^{\prime \prime}}\right), 139.4\left(\mathrm{C}_{1,7}\right)$, 162.8-164.8 $\left(\mathrm{C}_{4^{\prime}} .4^{\prime \prime}\right), 183.1\left(\mathrm{C}_{3,5}\right)$. ESI-MS $m / z$ calc for $[\mathrm{M}+\mathrm{H}]^{+}:$313.11; found: 312.9 .

$(1 E, 4 Z, 6 E)-\quad 1,7 \quad$-bis(3-fluorophenyl)- $5 \quad$ hydroxyhepta- 1,4,6 -trien-3-one (6):

Yield 76\% (2.37 g) yellow-orange solid, $\mathrm{C}_{19} \mathrm{H}_{14} \mathrm{~F}_{2} \mathrm{O}_{2}$ [312.10 g/mol]; $R_{f}=0.49$ (HEX/EA = 95/5); m.p. $138.5{ }^{\circ} \mathrm{C} ;{ }^{1} \mathrm{H}-\mathrm{NMR}\left(500 \mathrm{MHz}, \mathrm{CDCl}_{3}\right): \delta(\mathrm{ppm})=$ $5.85\left(s, \mathrm{H}_{4}, 1 \mathrm{H}\right), 6.61\left(d, \mathrm{H}_{2,6},{ }^{3} J(\mathrm{H}, \mathrm{H})=15.5 \mathrm{~Hz}\right.$, $2 \mathrm{H}), 7.07\left(m, \mathrm{H}_{5^{\prime}, 5^{\prime \prime}}, 2 \mathrm{H}\right), 7.25\left(d, \mathrm{H}_{6^{\prime}, 6^{\prime \prime}},{ }^{3} J(\mathrm{H}, \mathrm{H})=\right.$ $8.0 \mathrm{~Hz}, 2 \mathrm{H}), 7.31\left(d, \mathrm{H}_{2^{\prime}, 2^{\prime \prime}},{ }^{3} J(\mathrm{H}, \mathrm{H})=8.0 \mathrm{~Hz}, 2 \mathrm{H}\right)$, $7.36\left(m, \mathrm{H}_{4^{\prime}, 4^{\prime \prime}}, 2 \mathrm{H}\right), 7.62\left(d, \mathrm{H}_{1,7},{ }^{3} J(\mathrm{H}, \mathrm{H})=16.0 \mathrm{~Hz}\right.$, 2H). ${ }^{13} \mathrm{C}-\mathrm{NMR}\left(125 \mathrm{MHz}, \mathrm{CDCl}_{3}\right): \delta(\mathrm{ppm})=102.2$ $\left(\mathrm{C}_{4}\right), 114.1-114.3\left(\mathrm{C}_{4^{\prime}, 4^{\prime \prime}}\right), 116.9-117.1\left(\mathrm{C}_{2^{\prime}, 2^{\prime \prime}}\right), 124.2-$ $124.3\left(\mathrm{C}_{2,6}\right), 125.2\left(\mathrm{C}_{6^{\prime}, 6^{\prime \prime}}\right), 130.4-130.5\left(\mathrm{C}_{5^{\prime}, 5^{\prime \prime}}\right)$, 137.2-137.3 $\left(\mathrm{C}_{1^{\prime}, 1^{\prime \prime}}\right), 139.4-139.5\left(\mathrm{C}_{1,7}\right), 162.1-164.1$ $\left(\mathrm{C}_{3^{\prime}, 3^{\prime \prime}}\right), 183.0\left(\mathrm{C}_{3,5}\right)$. ESI-MS $m / z$ calc for $[\mathrm{M}+\mathrm{H}]^{+}$: 313.11; found: 312.9 .

\section{DISCUSSION}

The details of the synthetic procedure of curcuminoids were discussed in literatures ${ }^{12,13,17}$. Generally, the synthetic yields are dependent on the nature and position of substituents on the aromatic rings of benzaldehyde analogs (Table 1). When the carbonyl group is more positively charged, the attack of an enolate as nucleophile on it becomes more accessible. The presence of the hydroxy group $(-\mathrm{OH})$, an electron-donating group at para-position on the aromatic ring, resulted in lower isolated yields (1: 53\%; 2 : 48\%), while higher yields (3: 55\%, 4: 72\%; 5: 66\%; 6: $76 \%)$ were obtained when benzaldehyde derivatives containing inductively electron-withdrawing groups (meta-OH/- $\mathrm{OCH}_{3} /-\mathrm{F}$ groups) were used as starting materials. Adding one more fluoro group to 6 (76\%) on the para-position resulted in a small decrease in the yield (4: $72 \%$ ), confirming the negative effect of the resonance electron-donating group at para-position on the reaction yield.

Chemical structures of the synthesized compounds were elucidated by NMR and MS spectra. The presence of a singlet signal with one proton in a range from 5.80 to $6.40 \mathrm{ppm}$ in ${ }^{1} \mathrm{H}$-NMR spectra indicates that the enol forms of products (1-6) are predominant. Furthermore, the ${ }^{3} J_{H-H}$ values of $\sim 16.0 \mathrm{~Hz}$ of two doublet signals between 6.50 and 7.80 ppm were indicators of trans-configurations in the seven-carbon chain of curcuminoid structures.

Six target compounds were tested for cytotoxicity against human oral epidermal carcinoma-KB cell line using MTT method. The curcumin derivatives showed inhibitory activities toward KB (Table 1). A better insight into the mode of action of curcumin in the oral cancer cell is pivotal for the development of new curcumin-based antitumor agents. When the $\mathrm{KB}$ cells were treated with curcumin, the observations of Jeon et al. on the nuclear morphology in cells revealed that the apoptotic cell death was attributed to the nuclear condensation and fragmentation as well as internucleosomal DNA fragmentation ${ }^{14}$. Considering the chemically structural characteristics, curcuminoids are classified as an $a$, -unsaturated ketone, in which the $C_{\beta}$ is activated by the carbonyl group and it becomes electrophilic, also called a Michael acceptor center. The ability of curcumin to selectively induce apoptosis in cancer cells can be explained through the detoxification mechanism, which has received much attention among possible mechanisms to elucidate the complex nature of interactions of curcumin with biological molecules ${ }^{20-23}$. In that respect, the Michael acceptor center of curcumin structure is much prone to nucleophilic addition with the available $-\mathrm{SH}$ groups and glutathione (GSH), which can invalidate toxic agents in cells. This may lead to the cytotoxicity of curcuminoids against cancer cell lines. The removal of methoxy groups from the structure of lead compound $\left(1, \mathrm{IC}_{50}=33.35 \pm 2.66 \mu \mathrm{M}\right)$ resulted in a decrease in anti-cancer activity against $\mathrm{KB}\left(2, \mathrm{IC}_{50}=43.94 \pm 3.18 \mu \mathrm{M}\right)$. The result suggested that the meta-methoxy substituent was beneficial to the cytotoxicity. It should be noted that the potency of compound $3\left(\mathrm{IC}_{50}=15.61 \pm 0.13 \mu \mathrm{M}\right)$ bearing 2 -fold improved $\mathrm{OH}$ group at meta-position in the aromatic ring over curcumin (1). The stronger anticarcinogenic property of curcumin analogs containing substituted -OH group at meta or ortho positions compared to curcumin was reported in the literature, 
but the mechanism has remained unclear ${ }^{12,15,23,24}$. Here, our finding indicated a similar trend when curcuminoids were assayed toward $\mathrm{KB}$ cancer cell line. Curcuminoids bearing $-\mathrm{OH}$ groups displayed anti-cancer activities against $\mathrm{KB}$ higher than the fluorinated analogs $(2>5,3>6)$. The designed 4-fluorinated curcumin analogue $\left(\mathbf{5}, \quad \mathrm{IC}_{50}=\right.$ $366.19 \pm 28.48 \mu \mathrm{M})$ dramatically reduced activity in comparison with $\left(2, \mathrm{IC}_{50}=43.94 \pm 3.18 \mu \mathrm{M}\right)$. The replacement of $-\mathrm{OH}$ and $-\mathrm{OCH}_{3}$ of $\left(1, \mathrm{IC}_{50}\right.$ $=3.35 \pm 2.66 \mu \mathrm{M})$ by two fluorine atoms $\left(4, \mathrm{IC}_{50}\right.$ $=66.36 \pm 5.80 \mu \mathrm{M}$ ) leads to a 2 -fold reduction in anti-cancer capacity. The lower activities of $(4,5)$ obviously resulted from the existence of fluorine atoms in the aromatic rings. The apoptotic activity of curcumin correlated closely with the formation of reactive oxygen species (ROS). Compounds (1) and (2) can lose an $\mathrm{H}$-atom from the phenolic group to form phenoxyl radicals, which are stabilized by the conjugated system in their structure. The reactive free radicals are directly involved in cell apoptosis by attacking the cellular DNA strands ${ }^{15,25-27}$. In this context, the lower inhibitory activities of (4) and (5) can be attributed to the alteration of electronic properties of the fluorinated aromatic rings, due to which the formation of free radicals is unfavorable when compared to structures containing phenolic motifs.

In addition, the hydrophobic nature of the curcumin molecule often limits its bioavailability due to its poor absorption and penetration through the cell membrane. Fluorine substituent affects the physical properties of molecules, and aromatic fluorination always increases their lipophilicity ${ }^{28}$. The decreased cytotoxicity of the fluoro-substituted curcumin analogs $(4,5)$ can be due to their increased lipophilicities.

Interestingly, regardless of the presence of fluorine, the 3-fluorinated compound $\left(6, \mathrm{IC}_{50}=22.65 \pm 1.76\right.$ $\mu \mathrm{M})$ showed higher anticancer activity than (1) and (2). It might be concluded that the effect of the metaposition of -OH or -F substitution in the aromatic ring is crucial for anti-cancer activity against the $\mathrm{KB}$ cell line.

\section{CONCLUSION}

Six curcumin-based analogs were synthesized and evaluated for anti-cancer activities against the $\mathrm{KB}$ cancer cell line. The position and nature of substituents affect the isolated yields and cytotoxic activities. The synthetic yields of products containing electron-donating groups (1-3) are lower when compared to those of analogs (4-6) prepared from fluorinated benzaldehydes as starting materials. Fluorine atoms at para or both para/meta positions in compounds $(4,5)$ exhibited lower activities against the KB cell line than those of compounds (1-3). Structureactivity relationship analysis suggested that i) the ability of inhibitory activity of synthesized curcumin analogs might rely on detoxification mechanism. ii) The phenolic motif is responsible for better inhibition of cell growth, whereas the fluoro substituents in the aromatic ring make a negative contribution to inhibitory activity. iii) the effects of $-\mathrm{OH} /-\mathrm{F}$ groups at meta-position in the aromatic ring of $(\mathbf{3}, \mathbf{6})$ on the cytotoxicity against KB are remarkable and firstly reported in our findings. In general, we have provided more promising results from curcumin-based agents against the KB cancer cell line.

\section{LIST OF ABBREVIATIONS}

DCM: Dichloromethane

EA: Ethyl acetate

HEX: $n$-Hexane

KB: Human oral epidermal carcinoma cell line

IC $_{50}$ : Half-maximal inhibitory concentration

MTT: (3-(4,5-dimethylthiazol-2-yl)- 2,5 - diphenyltetrazolium bromide

SAR: Structure-activity relationship

NMR: Nuclear magnetic resonance

HSQC: Heteronuclear single quantum correlation

TLC: Thin layer chromatography

CC: Column chromatography

MS: Mass spectrometry

ROS: reactive oxygen species

\section{AUTHOR CONTRIBUTIONS}

Conceptualization: Hoang Minh Hao, Vo Thi Nga, and Pham Nguyen Kim Tuyen; synthesis of curcuminoids: Phan Phuoc Hoai Nhan and Hoang Minh Hao; structural assignment via NMR, MS, and analysis of cytotoxicity basing on structure: Hoang Minh Hao, Vo Thi Nga, and Pham Nguyen Kim Tuyen; writingoriginal draft preparation: Phan Phuoc Hoai Nhan and Hoang Minh Hao; writing-review and editing: Hoang Minh Hao. All authors have read and agreed to the published version of the manuscript.

\section{COMPETING INTERESTS}

The authors declare that they have no competing interests.

\section{SUPPORTING INFORMATION}

Chemicals used for the synthetic procedure, cytotoxicity assay, and NMR and MS spectra of curcuminoids (1-6) can be found in the Supporting Information. 


\section{ACKNOWLEDGMENT}

This work belongs to the project grant No: B2020SPK-05 funded by the Ministry of Education and Training, and hosted by Ho Chi Minh City University of Technology and Education, Vietnam.

\section{REFERENCES}

1. Eagle $H$. Propagation in a fluid medium of a human epidermoid carcinoma, strain KB. Exp Biol Med 1955;89:362364;PMID: 13254761. Available from: https://doi.org/10.3181/ 00379727-89-21811.

2. Bray F, Ferlay J, Soerjomataram I, Siegel RL, Torre LA, Jemal A. Global cancer statistics 2018: GLOBOCAN estimates of incidence and mortality worldwide for 36 cancers in 185 countries. CA Cancer J Clin 2018;68:394-424;PMID: 30207593. Available from: https://doi.org/10.3322/caac.21492.

3. Siegel RL, Miller KD, Jemal A. Cancer statistics. CA Cancer Clin 2018;68:7-30. https://doi.org/10.3322/caac.21442;PMID: 29313949. Available from: https://doi.org/10.3322/caac.21442.

4. Wu CP, Ohnuma $S$, Ambudkar SV. Discovering natural product modulators to overcome multidrug resistance in cancer chemotherapy. Curr Pharm Biotechnol 2011;12:609620;PMID: 21118092. Available from: https://doi.org/10.2174/ 138920111795163887.

5. Pulla Reddy AC, Lokesh BR. Studies on spice principles as anti-oxidants in the inhibition of lipid peroxidation of rat liver microsomes. Mol Cell Biochem 1992;111:117-124;PMID 1588934. Available from: https://doi.org/10.1007/BF00229582.

6. Xu YX, Pindolia KR, Janakiraman N, Chapman RA, Gautam SC. Curcumin inhibits IL1 alpha and TNF-alpha induction of AP-1 and NF-kB DNA-binding activity in bone marrow stromal cells. Hematopathol Mol Hematol 1997;11:49-62;.

7. Simoni D, Rizzi M, Rondanin R, Baruchello R, Marchetti $P$, Invidiata $\mathrm{FP}$, et al. Anti-tumor effects of curcumin and structurally $\beta$-diketone modified analogs on multidrug resistant cancer cells. Bioorg Med Chem Lett 2008;18:845-849;PMID: 18039573. Available from: https://doi.org/10.1016/j.bmcl. 2007.11.021.

8. Vyas A, Dandawate P, Padhye S, Ahmad A, Sarkar F. Perspectives on new synthetic curcumin analogs and their potential anti-cancer properties. Curr Pharm Des 2013;19:20472069;PMID: 23116312. Available from: https://doi.org/10. 2174/1381612811319110007.

9. Tomeh M, Hadianamrei R, Zhao X. A review of curcumin and its derivatives as anti-cancer agents. Int J Mol Sci 2019;20:26 pages;Available from: https://doi.org/10.3390/ijms20051033.

10. Theppawong A, Van de Walle T, Grootaert C, Van Hecke K, Catry N, Desmet T, et al. Synthesis of nonsymmetrical nitrogen-containing curcuminoids in the pursuit of new anti-cancer candidates. ChemistryOpen 2019;8:236-247;PMID: 30847262. Available from: https://doi.org/10.1002/open.201800287.

11. Theppawong A, Van de Walle T, Van Hecke K, Grootaert C, Van Camp J, D'hooghe M. Synthesis of 1,4-thiazepane-based curcuminoids with promising anti-cancer activity. Chem - Eur J 2019;25:12583-12600;PMID: 31283064. Available from: https: //doi.org/10.1002/chem.201902549.

12. Pham VTB, Nguyen TV, Nguyen HV, Nguyen TT, Hoang HM Curcuminoids versus pyrazole-modified analogs: synthesis and cytotoxicity against HepG2 cancer cell line. ChemistrySelect 2020;5:11681-11684;Available from: https://doi.org/10. 1002/slct.202003003.

13. Phan NPH, Pham VTB, Phan TDQ, Pham TNK, Hoang HM. Cytotoxic activities of synthesized curcumin and 3,4-Difluorinated curcumin against HepG2, LU-1 and KB cancer cell lines. Sci Technol Dev J 2020;23:781-787;Available from: https://doi. org/10.32508/stdj.v23i4.2464

14. Jeon $\mathrm{H}-\mathrm{S}$, Jo M-H, Kim H-J, Lee M-H, Yu S-K, Kim CS, et al. Anti-cancer activities of diphenyl difluoroketone, a novel curcumin analog, on KB human oral cancer cells. J Korean Soc Appl Biol Chem 2012;55:451-456;Available from: https://doi. org/10.1007/s13765-012-1168-8.

15. Chuprajob T, Changtam C, Chokchaisiri R, Chunglok W, Sornkaew N, Suksamrarn A. Synthesis, cytotoxicity against human oral cancer KB cells and structure-activity relationship studies of trienone analogs of curcuminoids. Bioorg Med Chem Lett 2014;24:2839-2844;PMID: 24857542. Available from: https://doi.org/10.1016/j.bmcl.2014.04.105.

16. Zhao $\mathrm{S}, \mathrm{Pi} \mathrm{C}, \mathrm{Ye} \mathrm{Y}$, Zhao $\mathrm{L}$, Wei $\mathrm{Y}$. Recent advances of analogs of curcumin for treatment of cancer. Eur J Med Chem 2019;180:524-535;PMID: 31336310. Available from: https:// doi.org/10.1016/j.ejmech.2019.07.034.

17. Nagahama K, Utsumi T, Kumano T, Maekawa S, Oyama N, Kawakami J. Discovery of a new function of curcumin which enhances its anti-cancer therapeutic potency. Sci Rep 2016;6:14 pages;Available from: https://doi.org/10.1038/ srep30962.

18. Krackov MH, Bellis HE. Process for the synthesis of curcuminrelated compounds. US5679864A. 1997;

19. Pabon HJJ. A synthesis of curcumin and related compounds. Recl Trav Chim Pays-Bas 1964;83:379-386;Available from: https://doi.org/10.1002/recl.19640830407.

20. Labbozzetta M, Baruchello R, Marchetti P, Gueli MC, Poma P Notarbartolo M, et al. Lack of nucleophilic addition in the isoxazole and pyrazole diketone modified analogs of curcumin; implications for their anti-tumor and chemosensitizing activities. Chem Biol Interact 2009;181:29-36;PMID: 19539615. Available from: https://doi.org/10.1016/j.cbi.2009.06.005.

21. Awasthi S, Pandya U, Singhal SS, Lin JT, Thiviyanathan V, Seifert WE, et al. Curcumin-glutathione interactions and the role of human glutathione S-transferase P1-1. Chem Biol Interact 2000;128:19-38;Available from: https://doi.org/10.1016/ S0009-2797(00)00185-X.

22. Dinkova-Kostova AT, Talalay P. Relation of structure of curcumin analogs to their potencies as inducers of Phase 2 detoxification enzymes. Carcinogenesis 1999;20:911-914;PMID: 10334211. Available from: https://doi.org/10.1093/carcin/20.5.911.

23. Devasena T. Bis-1,7-(2-hydroxyphenyl)-hepta-1,6-diene-3,5dione (a curcumin analog) ameliorates DMH-induced hepatic oxidative stress during colon carcinogenesis. Pharmacol Res 2002;46:39-45;Available from: https://doi.org/10.1016/S10436618(02)00043-9.

24. Anto R. Anti-tumour and free radical scavenging activity of synthetic curcuminoids. Int J Pharm 1996;131:1-7;Available from: https://doi.org/10.1016/0378-5173(95)04254-7.

25. Sökmen $M$, Akram Khan $M$. The anti-oxidant activity of some curcuminoids and chalcones. Inflammopharmacology 2016;24:81-86;Available from: https://doi.org/10.1007/s10787016-0264-5PMid:27188988.

26. Mishra S, Kapoor N, Mubarak Ali A, Pardhasaradhi BVV, Kumari $A L$, Khar A, et al. Differential apoptotic and redox regulatory activities of curcumin and its derivatives. Free Radic Biol Med 2005;38:1353-1360;PMID: 15855053. Available from: https:// doi.org/10.1016/j.freeradbiomed.2005.01.022.

27. Cerutti PA. Oxidant stress and carcinogenesis. Eur J Clin Invest 1991;21:1-5;PMID: 1907547. Available from: https://doi.org/ 10.1111/j.1365-2362.1991.tb01350.x.

28. Smart BE. Fluorine substituent effects (on bioactivity). J Fluor Chem 2001;109:3-11;Available from: https://doi.org/10.1016/ S0022-1139(01)00375-X. 